\title{
THE DIVINE LITURGY AS MYSTICAL EXPERIENCE
}

\section{DAVID BRADSHAW}

\author{
University of Kentucky
}

\begin{abstract}
Most characterizations of mystical experience emphasize its private, esoteric, and non-sensory nature. Such an understanding is far removed from the original meaning of the term mystikos. For the ancient Greeks, the 'mystical' was that which led participants into the awareness of a higher reality, as in the initiatory rites of the ancient mystery cults. This usage was taken over by the early Church, which similarly designated the Christian sacraments and their rites as 'mystical' because they draw participants into a higher level of reality. I argue that the Divine Liturgy is a form of 'mystical experience' in this sense, and that philosophers have missed a great deal by excluding such communal acts from the scope of mystical experience.
\end{abstract}

Eastern Orthodoxy holds what may appear to the non-Orthodox to be a remarkably exalted view of the status and significance of its liturgical services. Possessing no Pope, magisterium, or universally agreed catechism, and for many years being unable (owing to various forms of persecution) openly to teach their faith, the Orthodox have long looked to the divine services as the surest and most profound repository of Orthodox theology. St. Theophan the Recluse, a nineteenth-century Russian monk and bishop, well expressed this attitude of reverence:

All of our liturgical hymns are instructive, profound, and sublime. They contain the whole of our theology and moral teaching, give us Christian consolation, and instil in us a fear of the Judgment. He who listens to them attentively has no need of other books on the Faith. ${ }^{1}$

${ }^{1}$ Quoted in Bishop (now Metropolitan) Hilarion Alfeyev, 'Orthodox Worship as a School of Theology’, Kiev Theological Academy, 20 September 2002. Available at: $<$ http://orthodoxeurope.org/page/12/1.aspx> [accessed 28 February 2014]. 
More recently, Metropolitan Hilarion Alfeyev, in a lecture entitled 'Orthodox Worship as a School of Theology', has discussed at length the theological content of the divine services. He adds, however, that the value of the services does not lie exclusively or even primarily in their teaching function, but in their power of placing man in the presence of God. Everything about the services - including not only the words, but the architecture and ornamentation of the church, the icons, the chanting, the candles, the incense, the liturgical vestments, the making of the cross, the kneeling and prostrating, and the processions of the clergy - constitutes a single harmonious whole, a kind of perpetually enacted drama in which all have a role. Crucially, the drama is not limited to its earthly participants but incorporates God himself as auditor and (through the reading of Scripture) as speaker. Metropolitan Hilarion quotes in this regard another Russian of the nineteenth century, St. Ignatius Brianchaninov, whose description of traditional Russian chant captures something of this sense of a continual ongoing interchange with God:

The tones of this chant are majestic and protracted ... they depict the groans of the repentant soul, sighing and longing in the land of its exile for the blessed, desired country of eternal rejoicing and pure, holy delights ... These tones now drag on lugubriously, melancholically, drearily, like a wind through the wilderness, now gradually disappear like an echo among cliffs and gorges, now thunder suddenly ... The majestic 'Lord, have mercy' is like a wind through a desolate place, so sorrowful, moving, and drawn out. The troparion 'We hymn thee' ends with a protracted, shimmering, overflowing sound, gradually abating and imperceptibly fading under the vaults of the church, just as an echo dies out under a church's arches. And when the brethren sing at vespers, 'Lord, I have cried unto Thee, hearken unto me', the sounds emanate as if from a deep abyss, are quickly and thunderously wrested therefrom and rise to heaven like lightning, taking with them the thoughts and wishes of those at prayer. Everything here is full of significance and majesty, and anything merry, light-hearted, or playful would simply seem strange and ugly. ${ }^{2}$

Above all it is in the Divine Liturgy, the Eucharistic service celebrated on Sundays and feast days, that God is felt to be palpably present. Metropolitan Hilarion writes of it as follows:

\footnotetext{
${ }^{2}$ Quoted in Hilarion Alfeyev, 'Orthodox Worship’.
} 
If we can call the services of the Orthodox Church a school of theology, then the Divine Liturgy is this school par excellence. It teaches us about the mysteries of the Heavenly Kingdom because it itself is an icon of this Kingdom, the most complete, perfect reflection of the heavenly reality in our earthly conditions, a revelation of the transcendent through the immanent ... If [in the Heavenly Kingdom] the manner of our communion with God will change, its essence will remain the same - always a personal encounter with God, not of isolated people, but of people in communion with each other. In this sense it is correctly said that the Liturgy served on earth is but a part of the incessant Liturgy celebrated by people and angels in the Heavenly Kingdom. ${ }^{3}$

As I will explain more fully later, such a view of the Liturgy is in fact contained within the prayers and hymns of the Liturgy itself. If all the divine services are a means of engaging God and entering into His presence, in the Divine Liturgy this is pre-eminently so, for it is in the Eucharist above all that God becomes tangibly present and offers His life to be shared by the faithful.

The question I wish to ask in this paper is whether the Divine Liturgy ought to be considered a form of mystical experience. Admittedly, from the standpoint of most contemporary discussions of mysticism such a question may appear strange, for as a corporate and ritual act the Liturgy does not seem to fit the typical understanding of mysticism. This becomes clear when we turn to some prominent attempts to characterize 'mystical experience'. William James in his classic work, The Varieties of Religious Experience, offers one such attempt. He holds that mystical experience is characterized by four features:

(1) ineffability, i.e., 'no adequate report of its content can be given in words';

(2) noetic quality, i.e., mystical states are 'states of insight into depths of truth unplumbed by the discursive intellect';

(3) transiency, i.e., they last a relatively short time;

(4) passivity, i.e., 'the mystic feels as if his own will were in abeyance, and indeed sometimes as if he were grasped and held by a superior power. ${ }^{4}$

${ }^{3}$ Ibid.

${ }^{4}$ William James, The Varieties of Religious Experience (New York: Macmillan, 1961), pp. 299-300. 
One might argue that, in a very loose sense, the experience of the Liturgy fits these characteristics. Its noetic quality, for example, is evident in the statement of Metropolitan Hilarion that the Liturgy 'teaches us about the mysteries of the Heavenly Kingdom'. Likewise it is arguably ineffable, for the prayers said by the priest refer to the Eucharistic gifts as 'mysteries' that are received upon God's 'holy, celestial, and spiritual altar.'

Yet it plain from the entire tenor of James's discussion that such an argument would misunderstand his meaning. The examples he offers are of ecstatic or otherwise extraordinary states undergone by individuals, not of a condition achieved ritually and repeatedly in communion with others. In fact, in speaking of 'the experience of the Liturgy' one does not pick out a specific state of consciousness at all, but only whatever is shared by the many worshippers in virtue of their common action. Their states of consciousness will inevitably vary widely during the course of the Liturgy, and even from one person to another at a given moment; one may be focused rapturously on the service, while another is attending to executing some required act, and another is daydreaming. For this reason, one can speak of 'the experience of the Liturgy' only in the rather loose and generic way that one speaks of, say, 'the experience of a football game' or 'the experience of going to high school'.

This objection would be fatal were James's understanding of mysticism the only one available. However, James's definition has been widely criticized on various counts, including its individualistic and subjectivist character. Is there a different result when we turn to more recent definitions? As an example we may take the Stanford Encyclopedia of Philosophy entry on 'Mysticism' by Jerome Gellman. ${ }^{6}$ Gellman defines 'mystical experience' as follows:

A (purportedly) super sense-perceptual or sub sense-perceptual experience granting acquaintance of realities or states of affairs that are of a kind not accessible by way of sense perception, somatosensory modalities, or standard introspection. ${ }^{7}$

${ }^{5}$ References to the Divine Liturgy will be to the Liturgy of St. John Chrysostom as printed in F. E. Brightman (ed.), Liturgies Eastern and Western (Oxford: Clarendon Press, 1896 [repr. 1965]), vol. 1, pp. 353-399. Most of the passages cited can also be found in the Liturgies of St. James and St. Basil.

${ }^{6}$ See <http://plato.stanford.edu/entries/mysticism> [accessed 28 February 2014].

7 Actually this is what Gellman calls mystical experience in the broad sense. That in the narrow sense is similar but limited to what Gellman calls 'unitive' experiences, that is, those that involve 'a phenomenological de-emphasis, blurring, or eradication of 
It will be noted that this definition uses the broad term 'experience'. It thus does not focus as resolutely upon exotic states of consciousness as does that of James; the focus is rather upon the contrast between mystical experience and that which is available through sense perception or other normal means. Gellman does caution, however, that he does not mean that the senses and other normal faculties play no role in mystical experience. In some cases they may provide a sort of substratum upon which the mystical element is 'overlaid', and when this happens the mystical experience is called 'extroverted'. Examples include 'one's mystical consciousness of the unity of nature overlaid onto one's sense perception of the world', as well as the sense of 'experiencing God's presence when gazing at a snowflake. ${ }^{8}$

In its contrast between mystical and sensory experience Gellman's discussion is similar to another influential recent account, that of William Alston. Alston distinguishes between direct experience of God, 'where there is no other object of experience in and through which God is experienced', and mediated experience, where 'one takes oneself to be aware of God through the beauties of nature, the words of the Bible or of a sermon, or other natural phenomena.' ${ }^{9}$ The direct experience of God may take two forms: sensory, where God appears in a sensible form, and non-sensory. Alston recognizes that both forms of direct experience (and perhaps some cases of indirect experience) may qualify as mystical experience in the ordinary sense of the term, but he chooses to focus solely on non-sensory cases of direct experience, explicitly limiting the term 'mystical experience' as he will use it to this category. He explains: 'The main reason for this choice is that since God is purely spiritual, a nonsensory experience has a greater chance of presenting $\mathrm{Him}$ as $\mathrm{He}$ is than any sensory experience. If God appears to us as bearing a certain shape or as speaking in a certain tone of voice, that is a long way from representing Him as He is in Himself. ${ }^{\prime 10}$

multiplicity'. Although Gellman focuses primarily on mystical experience in the narrow sense, for our purposes the broad sense is most relevant.

8 Jerome Gellman, 'Mysticism'.

9 William Alston, 'Religious Experience as Perception of God', in Steven M. Cahn (ed.), Ten Essential Texts in the Philosophy of Religion (New York and Oxford: Oxford University Press, 2005), pp. 440-449 (p. 441). See also William Alston, Perceiving God: The Epistemology of Religious Experience (Ithaca and London: Cornell University Press, 1991), pp. 20-28.

${ }_{10}$ William Alston, 'Religious Experience', p. 442. See also the similar statement in Perceiving God: 'If God appears to one, non-sensorily, as loving, powerful, or good, the 
One may well be brought up short by these last words, for the question of what it could mean to represent or to see God 'as He is in Himself' is one with a long and complex history. ${ }^{11}$ Alston, at any rate, takes it as obvious that the truest experience of God must be non-sensory. Much the same view would seem to be held by Gellman, for while Gellman recognizes the possibility of 'extroverted' mystical experience, in such experience the awareness of God merely accompanies or 'overlays' the sensory experience, rather than being integral to it.

Let us examine the extent to which such a view conforms with Jewish and Christian revelation. Consider the following episodes:

(1) God walking in the Garden of Eden with Adam and Eve (Gen. 3:8-19).

(2) Abraham entertaining three mysterious visitors, called 'men' although Abraham addresses them as 'Lord' and the story is introduced with the statement, 'the Lord appeared unto him in the plains of Mamre' (Gen. 18:1-16).

(3) Jacob wrestling with a man through the night and concluding, 'I have seen God face to face' (Gen. 32:24-32).

(4) Moses encountering God in the burning bush, the darkness upon Mount Sinai, and while hidden in 'a clift of the rock', where he sees God's 'backside' (Ex. 3:1-4:17, 19:3-20:21, 33:1-23).

(5) Elijah hearing a 'still small voice' and emerging from his cave to speak with the Lord (I Kings 19:11-19).

(6) The Holy Spirit descending 'in a bodily shape like a dove' upon Christ, accompanied by the voice of the Father (Lk.3:21-22).

(7) The Holy Spirit descending upon the apostles in 'cloven tongues like as of fire' (Acts 2:1-4).

These certainly seem to be cases where God appears directly and sensibly to man - indeed, does not only appear to him, but walks, speaks, dines, and even wrestles. There is no suggestion that, because God is 'purely

appearance, so far as it goes, could correspond fairly closely with the way God is Himself. While if we experience God as looking or sounding a certain way, that can't be the way He is, not even approximately.' (p. 20)

${ }^{11}$ For a helpful introduction to the topic see Vladimir Lossky, The Vision of God (Crestwood, NY: St. Vladimir's Seminary Press, 1973). I have addressed some of its complexities in 'The Vision of God in Philo of Alexandria', American Catholic Philosophical Quarterly, vol. 72 (1998), 483-500. 
spiritual', such appearances are not of God 'as He is in Himself'. On the contrary, many of these events occupy a central place within the Biblical narrative, serving to underscore the reality of God's ongoing, active presence within human affairs.

Some may be inclined to dismiss these events as simply too strange to carry much weight. I would urge the opposite view, that precisely because they ill consort with our preconceptions they should be taken all the more seriously. In any case, they do not stand alone, but must be seen in the context of another prominent Biblical theme: that of the divine glory. The divine glory appears repeatedly throughout the Old Testament - in the cloud that follows the Israelites in the wilderness, the darkness atop Mount Sinai, the Tabernacle, the Temple in Jerusalem, the visions of Ezekiel, and in frequent prophecies of a time when the whole earth will be filled with the glory of the Lord. ${ }^{12}$ The exact status of the divine glory is enigmatic, but it does not seem to be simply a creature, for it constitutes in some way the direct and unmediated presence of God. For example, we are told not only that the divine glory appeared in the Tabernacle, but that God himself appeared there (Lev. 16:2), and what Moses sees from the clift of the rock is described in virtually the same breath as God's 'glory' and His 'backside' (Ex. 33:22-23). ${ }^{13}$

In the New Testament, the divine glory appears most prominently at the Transfiguration. There Jesus's 'face did shine as the sun, and his raiment was white as the light' (Matt. 17:2), an event described explicitly as a manifestation of his glory (Lk. 9:32, II Peter 1:17). Although the Gospels speak of Jesus being transfigured, patristic interpreters noted that Jesus as God already possessed glory intrinsically, so that one might equally say that it was the disciples who were altered in coming to see him as he truly was. St. John of Damascus, for example, writes: 'He was transfigured, then: not taking on what he was not, nor being changed to what he was not, but making what he was visible to his own disciples, opening their eyes and enabling them, who had been blind, to see.'14 The

12 See Ex. 16:7, 10, 24:16-17, 40:34-35, Lev. 9:23, Num. 14:10, 21, 16:18, 42, 20:6, II Chron. 5:14, 7:1-3, Is. 6:3, 40:5, 60:1-3, Ezek. 1:28, 3:23, 8:4, 9:3, 10:4, 18-19, 11:22-23, 39:21, 43:2, Hab. 2:14, 3:3.

${ }^{13}$ See further David Bradshaw, 'The Divine Glory and the Divine Energies', Faith and Philosophy, vol. 23 (2006), 279-298.

${ }^{14}$ John of Damascus, 'Homily on the Transfiguration', sect. 12, Light on the Mountain: Greek Patristic and Byzantine Homilies on the Transfiguration, trans. Brian Daley (Crestwood, NY: St. Vladimir's Seminary Press, 2013), p. 221. 
same understanding is expressed in Orthodox hymnography, as in the apolytikion of the Feast of the Transfiguration: 'Thou wast transfigured upon the mountain, O Christ our God, showing Thy glory to Thy disciples as far as they were able to bear it. At the intercessions of the Theotokos, make thine everlasting light shine forth also upon us sinners. O Giver of light, glory to Thee. ${ }^{15}$

It is also important to note that the divine glory is not simply a way of announcing and underscoring the divine majesty, like the fanfare of trumpets accompanying a king. From a Christian standpoint, at least, it exists precisely in the communion of the divine Persons, and its function is (at least in part) that of ushering creatures into this communion. This is evident in the High Priestly prayer of John 17. The prayer begins with Jesus beseeching the Father that they may be mutually glorified: 'Father, the hour is come; glorify thy Son, that thy Son also may glorify thee' (v. 1), continuing a few verses later, 'And now, O Father, glorify thou me with thine own self with the glory which I had with thee before the world was' (v. 5). Clearly Jesus here speaks of the glory that is an intrinsic attribute of divinity. As the prayer continues, we see that he seeks to share this glory with his disciples, ushering them into the eternal communion between him and the Father: 'And the glory which thou hast given me I have given them, that they may be one, even as we are one ... Father, I will that they also, whom thou hast given me, be with me where I am; that they may behold my glory which thou hast given me, for thou lovest me before the foundation of the world' (v. 22-24). The divine glory, then, is not simply an extraneous show, but the means - indeed, the very substance - of communion. In revealing his glory to his disciples, Christ enables them to enter into his own communion with the Father.

I hope this brief exposition of the Biblical theophanies, and the Transfiguration in particular, will show how questionable is the assumption that only an experience of God as 'purely spiritual' can be veridical. The disciples in beholding Christ transfigured saw him with their eyes, albeit eyes transformed so as to be capable of seeing him as he truly is. Likewise it was the ordinary human senses that were at work when the Israelites beheld the divine glory in the cloud, the Tabernacle, and the Temple, and when Jacob wrestled with the stranger, Moses

15 Mother Mary and Archimandrite (now Metropolitan) Kallistos Ware, The Festal Menaion (South Canaan, PA: St. Tikhon's Seminary Press, 1990), pp. 477-478. Interestingly, the Scripture readings for Vespers of this feast recount the two encounters of Moses with God upon Mount Sinai and the episode of Elijah in the cave. 
encountered the burning bush, and Elijah heard the 'still, small voice'. All of these events took place not in some private mystical state, but in ordinary public space. They thus fit neither the strictures that Alston (and presumably Gellman) would place on a veridical encounter with God, nor the restriction of the mystical to private experience assumed by James.

James and the others might well reply, of course, that that is all well and good, but that such encounters are not 'mystical' as they are using the term. One can certainly stipulate that the mystical is to be restricted to extraordinary private states of consciousness. The question is whether, in doing so, one will be 'carving nature at the joints' - that is, whether such a definition appropriately identifies a philosophically significant subject matter, or whether it in fact renders invisible that which ought to be of primary interest. To resolve this question we must pay some attention to the long history and varied connotations of the 'mystical'. When one turns to this history, an important fact emerges: the mystical (that is, the $\mu v \sigma \tau ı \kappa o ́ \varsigma)$ originally had nothing to do with extraordinary states of consciousness! It instead pertained precisely to the sort of event or relationship epitomized by the Transfiguration: the use by God of the sensible, not only to reveal a higher reality, but to place the participants in communion with that reality. Precisely because it is a form of communion, the mystical in this sense is not typically private, but occurs within public space through the ordinary human senses. In a word, it is an initiation into divine reality, and like all initiation it is intrinsically communal, even when (as may sometimes be the case) the participant enters into it apart from others.

The relevant history has been brought to light by Louis Bouyer in an important essay entitled (rather too modestly), 'Mysticism: The History of a Word. ${ }^{16}$ Bouyer notes that the adjective $\mu \nu \sigma \tau$ เ from $\mu v \varepsilon \tilde{v} v$, meaning 'to shut' - particularly the eyes but also, in later usage,

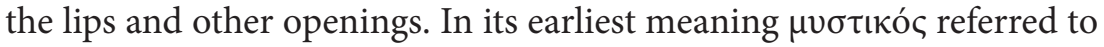
the rites of the mystery cults, which one approached with closed eyes and regarding which one was to keep one's lips sealed. By a natural extension it soon came to be applied, by Plato and others, to any form of knowledge reserved for the initiated. In this meaning it was taken up

${ }^{16}$ Louis Bouyer, 'Mysticism: An Essay on the History of a Word', Mystery and Mysticism: A Symposium, ed. by Albert Plé (London: Blackfriars, 1956), pp. 119-37; reprinted in Richard Woods (ed.), Understanding Mysticism (Garden City, NY: Doubleday, 1981), pp. $42-55$. 
by the Church Fathers, beginning with Clement of Alexandria. Because the true meaning of the Old Testament has been revealed in Christ, Clement referred to the Christian understanding of the Old Testament as the 'mystical interpretation', a usage that was soon popularized and extended by Origen. ${ }^{17}$ Although the term here no longer means secret, it still retains the core sense of that which is revealed to the initiated. From this beginning it came to be applied to all knowledge of divine things made available by Christ, as well as to the vehicles of initiation by which this knowledge is imparted. The Eucharist, in particular, was by the fourth century widely referred to by terms such as the 'mystical food', 'mystical banquet', and 'mystical sacrifice. Likewise chrism was referred to as 'mystical', and baptism was termed the 'mystical regeneration. ${ }^{18}$

Although the term $\mu v \sigma \tau$ เó itself is of Hellenic origin, I hope it will be plain from our discussion of the theophanies that the fundamental concept of an initiation into divine mysteries is Biblical. Of course whether the Eucharist and baptism in particular ought to be understood in this way is a further question. Without entering into the theology of the sacraments, it may be helpful to quote on this point the words of Bouyer. Alluding to the Pauline doctrine of the Church as the body of Christ, he writes:

Patristic spirituality and theology are dominated by the idea of the permanent and active presence of the Head himself [i.e., Christ] in the body, at one and the same time gathering its members into one, and giving them the power perpetually to re-enact what had taken place in him once and for all: his glorifying Cross, his passing from the life of the old Adam to the life of the new Adam, his passing from this world to the world to come, from this world to the Father ... Therefore, through all the uses which we have so far seen, we may say that it is always the same reality, at the same time so various and so profoundly one, which is expressed by the word mystical. Whether this reality is described as the final revelation of God's plan, discernible through all the Scriptures, and elaborated throughout all human history, or whether it is represented under the guise of the sacramental symbol which itself contains the object of this revelation, and is the means of realizing it in us, it is always this central Christian truth which is described by the word 'mystical. ${ }^{19}$

${ }^{17}$ Ibid., pp. 125-26; cf, G. W. H. Lampe, Patristic Greek Lexicon (Oxford: Clarendon

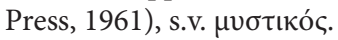

${ }^{18}$ Louis Bouyer, 'Mysticism', pp. 129-131.

${ }^{19}$ Ibid., pp. 131-132 (ellipsis dots in the original). 
It is, then, the belief in the Church as the body of Christ - a notion that St. Paul himself described as a 'great mystery' (Eph. 5:32) - that underlies the belief in the Eucharist and baptism as forms of mystical initiation, and, by extension, that in the Liturgy itself as a mystical rite.

Of course, in saying this I use the word 'mystical' in its ancient Christian sense. How, from this meaning, did it come to bear the modern sense analyzed by authors such as James and Gellman? A partial step in this direction - but only a partial one - was taken in the patristic era. Origen refers to the Christian meditation upon Scripture as 'mystical and ineffable contemplation', describing it as consisting in 'ineffable and mystical visions' that 'give joy and impart enthusiasm. ${ }^{20}$ In such phrases the term seems to indicate, not only the newly revealed Christian understanding of Scripture, but also, as Bouyer puts it, 'a certain way of knowing God, directly and as it were experimentally. ${ }^{21}$ From this usage the word naturally came to be used more broadly of particularly intense and elevated experiences (or states or conditions) in which God is encountered. Dionysius the Areopagite refers in this way to the Biblical theophanies as 'mystical visions', and to the ecstasy that was experienced by the apostles at the Dormition of the Theotokos as 'the mystical things

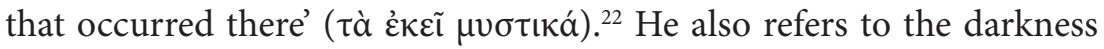
into which Moses ascended on Mount Sinai - an event he regards as a prototype of the ascent beyond merely conceptual knowledge to an actual encounter with God - as a penetration into 'the truly mystical

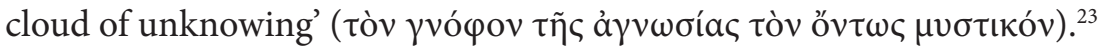
Finally, and perhaps most importantly from the standpoint of the history of the meaning of the word, he or an editor entitled the short work containing this discussion of Moses The Mystical Theology.

This work was read intensely throughout the Middle Ages, often in isolation from the rest of the Dionysian corpus. Thanks to its prominence, mysticus (which had been borrowed from Greek into Latin in the classical era) came to be the general term for any immediate encounter with or experience of God. Jean Gerson (1363-1429) offered what became

${ }^{20}$ Ibid., p. 133.

${ }^{21}$ Ibid., p. 132.

22 Dionysius the Areopagite, Divine Names, 1.6 596A, 3.3 684B; cf. 10.2 937B. See also Bernard McGinn, The Foundations of Mysticism: Origins to the Fifth Century (New York:

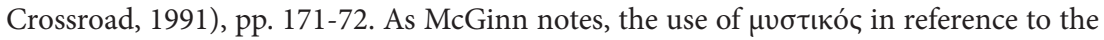
direct experience of God can also be found in the Macarian Homilies (p. 144).

${ }^{23}$ Dionysius the Areopagite, Mystical Theology, $1.31001 \mathrm{~A}$. 
a standard definition of mystical theology as cognitio Dei experimentalis, the experiential knowledge of God. ${ }^{24} \mathrm{He}$ sharply distinguishes such knowledge from that available through academic theology:

Mystical theology begins in the doctrine gathered from the internalized experiences lived in the hearts of devout souls, just as the other half of theology [i.e., academic theology, termed by Gerson theologia propria] proceeds from those matters that operate extrinsically. ${ }^{25}$

In the sixteenth and seventeenth centuries this bipartite division was further elaborated into the three-fold distinction of mystical theology, scholastic theology, and 'positive' (i.e., Biblical) theology. ${ }^{26}$ It was from this three-fold division that the contemporary understanding of mysticism as dealing primarily with private esoteric experiences arose.

This brief excursus into philology should make it clear that to refer to the Eucharist as a 'mystical supper', and to the Liturgy in which the Eucharist is consecrated and served as a 'mystical rite', is not an abuse of language, but belongs to the term's earliest Christian usage. It can, in fact, be found within the Liturgy itself. The prayers recited by the congregation immediately before partaking of communion refer to the Eucharist in precisely this way:

Of thy mystical supper, O Son of God, accept me today as a communicant; for I will not speak of thy mystery to thine enemies, neither will I give thee a kiss as did Judas, but like the thief will I confess thee: Remember me, O Lord, when thou comest into thy Kingdom.

The traditional icon of the Last Supper also uses the same term. It portrays Christ seated at a table surrounded by the twelve apostles, with the Passover meal before them and the words above, 'The Mystical Supper' (ó $\mu v \sigma \tau \iota \kappa o ́ \varsigma ~ \delta \varepsilon \tilde{\pi} \nu \circ \varsigma){ }^{27}$

${ }^{24}$ More fully, Gerson's definition is 'experiential knowledge of God gained through the embrace of unitive love'. Jean Gerson, Speculative Mystical Theology, Consid. 28, in The Presence of God: A History of Western Christian Mysticism, vol. 5, trans. Bernard McGinn (New York: Crossroad, 2012), p. 91.

${ }^{25}$ Ibid., Consid. 2, in Brian Patrick McGuire (trans.), Jean Gerson: Early Works (New York: Paulist Press, 1998), p. 266.

${ }^{26}$ See Michel de Certeau, The Mystic Fable, Volume One: The Sixteenth and Seventeenth Centuries (Chicago: University of Chicago Press, 1992), pp. 94-112, as well as the entries for 'mystic', 'mystical', and 'mysticism' in the Oxford English Dictionary.

${ }^{27}$ Examples can be found readily on the internet by searching the terms, icon mystikos deipnos'. 
Even so, it remains a further question what is meant by speaking of the Divine Liturgy as a mystical experience. Here we face the problem that, as I mentioned earlier, there is no single mental state that can be attributed to all participants in the Liturgy even at a single moment, much less over its entire course. Its cumulative effect as well no doubt differs greatly from one person to another, depending on factors such as individual piety, attention, and the ability to understand the language and the actions taken.

Indeed, when we turn to the Liturgy itself, we find that the predominant focus is less upon the thoughts or feelings of the participants than upon the objective reality of the action taking place. More specifically, it is upon the reality of the participation established between the worshipping community and the eternal heavenly Liturgy of the angels. In the words of Metropolitan Hilarion cited earlier, 'the Liturgy served on earth is but a part of the incessant Liturgy celebrated by people and angels in the Heavenly Kingdom'. That the angels are present and share in the actions performed is particularly evident at the two Entrances. At the outset of the Little Entrance the priest prays:

O Master, Lord our God, who hast appointed in heaven legions and hosts of angels and archangels for the service of thy glory, grant that with our entrance there may be an entrance of holy angels, serving with us and glorifying thy goodness...

The entrance of the angels is indicated symbolically by the fans carried by the acolytes, which depict the six-winged Seraphim, and the point is further underscored by the hymn sung at the conclusion of the Entrance, 'Holy God, Holy Mighty, Holy Immortal, have mercy on us', adapted from the hymn of the Seraphim in Isaiah 6.

At the Great Entrance the choir goes yet further, affirming not only that the angels are present but that the worshipping congregation is their image or 'icon'. That is the meaning of the Cherubic Hymn, sung as the priest enters bearing the chalice:

We who mystically represent the Cherubim, and who sing the Thriceholy Hymn to the Life-giving Trinity, let us lay aside all worldly care, that we may receive the King of All, who is coming invisibly escorted by the angelic hosts. Alleluia.

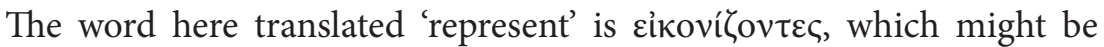
rendered literally, 'who are icons of'. The implication is that the worship 
offered by the congregation embodies, within space and time, the eternal worship of the angels around the throne of God. The same point emerges again later (just prior to the consecration) in the interchange of priest and choir. The priest prays in a subdued voice,

We thank thee also for this Liturgy which thou dost deign to receive from our hands, even though thou art surrounded by thousands of archangels and myriads of angels, by the Cherubim and Seraphim, which are sixwinged, many-eyed, and soar aloft on their wings.

He then raises his voice and chants, 'Singing, exclaiming, proclaiming the triumphal hymn and saying, at which point the choir responds, 'Holy, Holy, Holy, Lord of Sabaoth, heaven and earth are full of thy glory'. This is again the hymn - this time repeated verbatim - of the Seraphim in Isaiah 6 . Here again, then, we find the congregation taking on the role of the angels.

Much more could be said about the iconic nature of the Liturgy, as evident both in the text of the Liturgy itself and in patristic commentary. ${ }^{28}$ A fuller discussion would also have to take into account the architecture and ornamentation of the church, which have been designed - or rather, have developed organically through the centuries - so as to represent 'heaven on earth. ${ }^{29}$ But I hope that this brief review will suffice to introduce the idea and to indicate its centrality within the Liturgy itself.

What does the iconicity of the Liturgy imply about the experience of the individual worshipper? The first thing to bear in mind is that one never worships in the Liturgy simply as an individual, but only as a member of the worshipping congregation. In other words, the Liturgy is not so much an act one performs as a corporate act in which one shares. In this respect it resembles the performance of a symphony or dance, or even the playing of a team sport. One is always aware that the

${ }^{28}$ For helpful discussions see Metropolitan Kallistos Ware, 'The Meaning of the Divine Liturgy for the Byzantine Worshipper', in Church and People in Byzantium, ed. by Rosemary Morris (Birmingham: Centre for Byzantine, Ottoman, and Modern Greek Studies, 1986), pp. 7-28, and "It Is Time for the Lord to Act": The Divine Liturgy as Heaven on Earth', Sobornost, vol. 23/1 (2001), 7-22; also (now Bishop) Alexander Golitzin, 'Liturgy and Mysticism: The Experience of God in Eastern Orthodox Christianity', Pro Ecclesia, vol. 8 (1999), 159-86.

29 See Andrew Gould, 'On Earth as It Is in Heaven: Form and Meaning in Orthodox Architecture', available at: <http://www.newworldbyzantine.com/articles/ pdf/12571623810822660.pdf> [accessed 13 March 2014]. 
real action is not solely one's own, but that of the corporate whole in which one attempts, more or less adequately, to play one's part.

More than that, because the Liturgy itself is an icon of the heavenly Liturgy, the act is not even solely that of one's own congregation; it is that of all of creation joined in worship around the throne of the Creator. It is, in other words, not something that any earthly body creates by its own performance, but an eternally existing reality into which one enters, as a member of the body which is the Church, into communion. As we saw earlier, the Eucharist was from patristic times understood as 'mystical' in that it is the means of entering into communion with Christ. In the same way, the Liturgy as a whole is mystical in that it is the means of entering into communion with all of creation joined in worship of the Creator. Here 'mystical' has the meaning identified above in connection with Origen and Dionysius, that of indicating (to again quote Bouyer) 'a certain way of knowing God, directly and as it were experimentally'.

As for precisely what this experiential knowledge consists in, the best answer is that of the Psalmist: 'taste and see.. ${ }^{30}$ Even a lengthy description could not do justice to the many dimensions of the Liturgy, embracing as they do not only all of the senses - through the icons, candles, incense, vestments, making of the Cross, bowing and prostrations, liturgical processions, chanting, hymnody, and the worship space itself - but also the mind and the heart. One enters into heavenly worship as a whole person, and it is the whole person that is engaged and transformed in the process. To explicate all the dimensions of this engagement is beyond my purposes here, and would in any case be beyond my ability. My purpose has been the more limited one of arguing that, if we are to do justice to 'mystical experience' in all its forms, we must pay attention not only to the extraordinary private experiences that have traditionally been singled out for attention, but also to the communal experience of the worshipping Church.

30 'O taste and see that the Lord is good' (Psalm 34:8), often sung repetitively as a Communion hymn. 